\title{
Fra individuelt valg til samfundsproblem: Danske forebyggelsesstrategier på rygeområdet 1950-2010 sammenlignet med Sverige
}

\section{Betina Verwohlt}

Institut for Sociologi og Socialt Arbejde, Aalborg Universitet betina@cgs.aau.dk

Verwohlt, B. (2014). Fra individuelt valg til samfundsproblem: Danske forebyggelsesstrategier på rygeområdet 1950-2010 sammenlignet med Sverige. Tidsskrift for Forskning i Sygdom og Samfund, nr. 21, 109-135.

Indledning: Synet på tobakken har ændret sig drastisk de seneste 60 år, og der er, som konsekvens heraf, de seneste årtier implementeret særlig mange politiske interventioner overfor tobaksrygning. Formål: Artiklen analyserer udviklingen $i$ danske forebyggelsesstrategier fra 1950 til 2010 sammenlignet med Sverige, med særlig fokus på opfattelserne af statens og borgernes ansvar for at sikre en rogfri befolkning. Herefter diskuteres, hvorfor der er så stor forskel på udviklingen i dansk og svensk forebyggelseshistorie. Metode: Forebyggelsesstrategierne undersøges via systematisk litteratursøgning af 175 publikationer, som møder inklusionskriterierne. Publikationerne omfatter politiske dokumenter, publikationer med borgere som afsendere, WHO-rapporter, forskningsresultater og historiske oversigter. Resultater: Danske forebyggelsesstrategier består indtil 2000'erne primært $i$ at oplyse borgerne om rygningens skadevirkninger, og det anses generelt for borgerens eget ansvar at leve røgfrit, om det er det, man ønsker. Til sammenligning adresserer svenske forebyggelsestiltag allerede fra 1950'erne samfundets ansvar for en røgfri befolkning. Fra 2000'erne 
og frem problematiseres tobaksrygning også som et samfundsmæssigt problem i Danmark, og flere strukturorienterede tiltag implementeres i denne periode. Diskussion: Først med italesættelsen af passiv rygning som et arbejdsmiljøproblem bliver rygeproblematikken for alvor italesat som et samfundsproblem. Især synet på rygningen, forskningens vilkår $i$ offentligheden og den danske identitetsopfattelse ser ud til at indvirke på den træge danske udvikling.

\section{From individual choice to social problem: Prevention strategies in the smoking area in Denmark 1950-2010 compared to Sweden}

Introduction: The view on tobacco has changed drastically the past 60 years. Consequently, during the recent decades a range of policy interventions against smoking has been implemented. Aim: This article examines the development in prevention strategies in Denmark from 1950 to 2010 compared to Sweden, and it particularly focuses on the perceptions of the state's and citizens' responsibility to ensure a non-smoking population. Subsequently, the article addresses why there is such a difference in the development of Danish and Swedish prevention history. Method: The prevention strategies are explored through a systematic literature review of 175 publications that meet the inclusion criteria. The publications include policy documents, civic publications, WHO reports, research, and historical overviews. Results: Up until the 2000s, Danish prevention initiatives mainly consisted of information to the public about the harmful effects of smoking, and it is generally viewed as the citizen's own responsibility to live smoke-free. In comparison, Swedish prevention initiatives are already in the 1950s addressing societal responsibility for a population of non-smokers. From the 2000s onwards, tobacco consumption is increasingly viewed as a societal problem in Denmark and more structure-oriented initiatives are implemented during this period. Discussion: Not until the articulation of passive smoking as a working environment problem was the issues of smoking perceived as a societal problem. Especially the perception of smoking, the conditions of research in the public, and the Danish sense of identity seems to affect the sluggish Danish development.

\section{Indledning}

Der har de seneste årtier været særlig stor opmærksomhed på og forebyggende interventioner overfor tobaksrygning, da rygning er den livsstilsfaktor, der har størst negativ effekt på den ringe middellevetid i Danmark sammenlignet med andre vestlige lande (Kjøller, Juel og Kamper-Jørgensen, 2007). Og rygeprævalensen 
i Danmark har i mange år været høj. Som det fremgår af figur 1, røg 58 \% af alle danskere i 1950, mod blot 29 \% i Sverige. I 1965 var andelen steget til 62 \%, mens den i Sverige var steget til 43 \%. Fra 1970'erne faldt prævalensen i begge lande og er i 2010 på $20 \%$ i Danmark og $14 \%$ i Sverige 1 .

Figur 1: Dagligrygere blandt personer over 15 år i Danmark og Sverige, alle tobakstyper

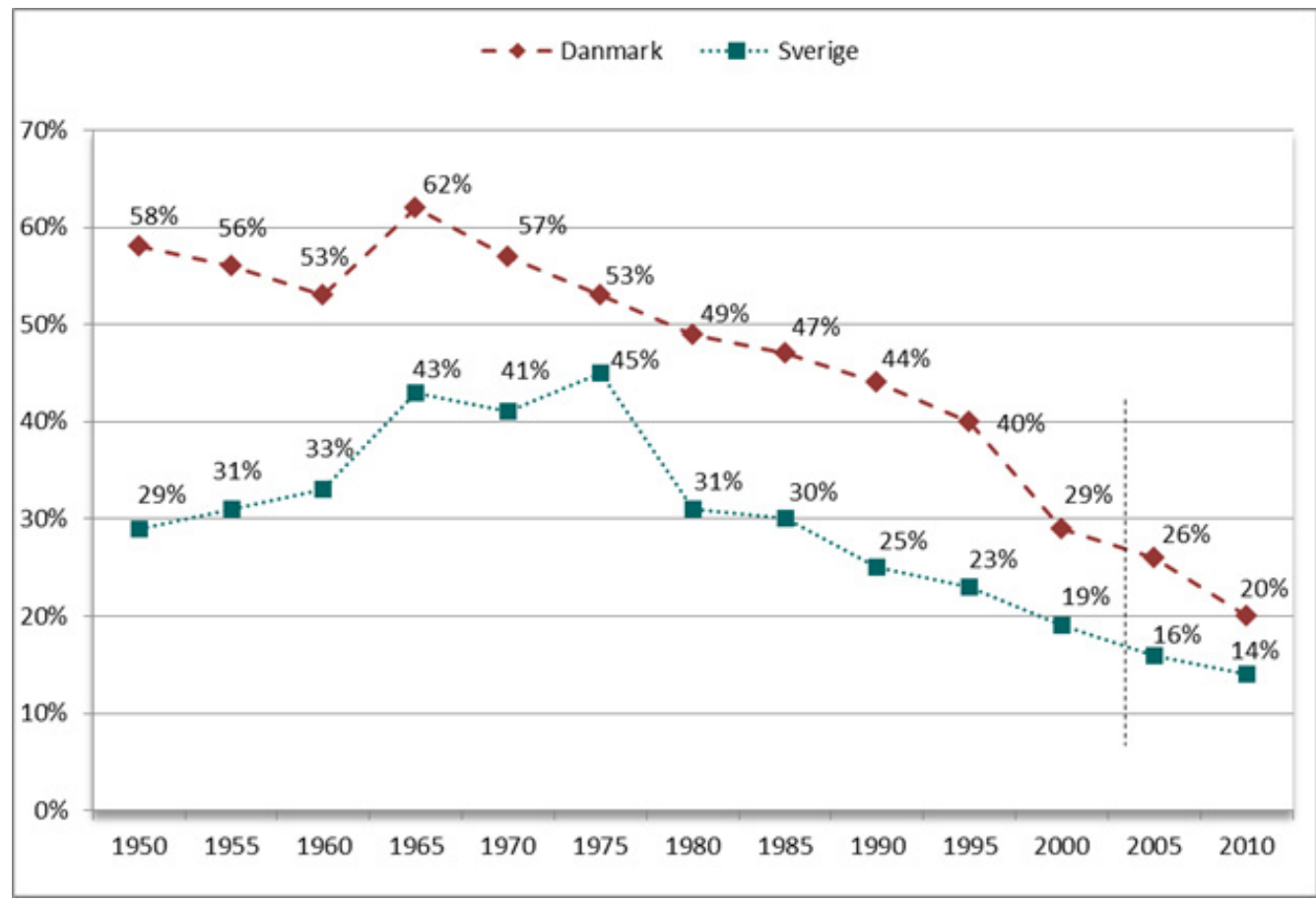

((Egen figur på baggrund af Forey et al 2002 (1950-2000) og OECD 2011(2005-2010).

De stiplede linjer indikerer, at prævalensen af dagligrygere ikke er kendt mellem undersøgelsesnedslagene.)

Lige såvel som rygeprævalensen har ændret sig markant gennem de sidste 60 år, har også synet på tobakken undergået en markant statusændring fra at blive opfattet som sofistikeret vane - over et farligt, men individuelt valg - til et samfundsproblem. Indlejret i fremstillingen af tobakken ligger også immanent indikationer på, hvorvidt tobaksrygning skal forebygges og i så fald, hvem der har ansvaret for en røgfri befolkning. Men ansvarsplaceringen er en kompleks størrelse. På den ene side står statens råd og reguleringer, i det mindste umiddelbart, i kontrast til den personlige frihed og det personlige handlerum. På den anden side har borgerne ${ }^{2}$ selv et ansvar for ikke at leve usundt under påråbelse af den personlige frihed, som vi et langt stykke hen ad vejen netop kan takke andre for 
(Jørgensen, 2011). Placeres ansvaret primært hos den enkelte borger, risikerer man en 'blaming the victim' tilgang, hvor sygdom er selvforskyldt. Placeres ansvaret derimod primært hos samfundet, er risikoen individuel ansvarsfralæggelse, hvor dårligt helbred bliver 'samfundets skyld'3.

Teoretisk kan der sondres mellem strukturorienterede og individorienterede forebyggelsesstrategier. De strukturorienterede strategier adresserer samfundets ansvar for at indrette samfundet, så det bliver lettere at leve sundt og sværere at leve usundt. Det er strategier som lov om røgfrie miljøer, punktafgifter på tobaksvarer, forbud mod tobaksreklamer, advarselstekst på tobaksvarer, nem adgang til nikotinprodukter og aldersgrænse for $k ø b$ af tobaksvarer. Individorienterede forebyggelsesstrategier er strategier, der adresserer borgernes ansvar for at leve sundt, såsom rygestopkurser og oplysningskampagner, der informerer borgerne om rygningens skadevirkninger (Glümer et al, 2010:14-16). De forskellige typer initiativer har effekt på forskellige befolkningsgrupper. Individorienterede strategier har tendens til at påvirke socioøkonomisk velstillede borgere til at ændre rygeadfærd, men til gengæld har de en ringe effekt på socioøkonomisk dårligt stillede, hvilket øger den sociale ulighed i sundhed (Ekholm, 2006, Kjøller, Juel og Kamper-Jørgensen, 2007). Strukturorienterede strategier har derimod mere lige effekt på hele befolkningen og er, ifølge WHO, de mest effektive (David et al., 2010). I praksis ses ofte en kombination af de to strategier, som dog kan vægtes forskelligt.

\section{Formål}

Artiklen består af en beskrivende og en diskuterende del. I den beskrivende del gennemgås de forskellige forebyggelsesstrategier i kronologisk rækkefølge i henholdsvis Danmark og Sverige, idet der fokuseres på, om strategierne primært adresserer individets ansvar for at holde op med at ryge eller samfundets ansvar for at skabe rammer, der lægger op til røgfrie liv. Ansvarsplaceringen problematiseres ${ }^{4}$ sjældent på forebyggelsesområdet til trods for, at den er yderst vigtig for, hvor effektivt det forebyggende arbejde er samt for, hvem der responderer herpå (Verwohlt og Reinbacher, 2012). 1950'erne udgør starttidspunktet for den beskrivende analyse, eftersom tobakkens status fra denne periode ændredes fra primært at blive opfattet som et uskyldigt socialt indslag til at blive opfattet som et sundhedsmæssigt problem, som kræver politisk styring. De danske forebyggelsesstrategier sammenlignes med strategierne i Sverige, eftersom et komparativt 
grundlag er velegnet til at identificere forskelle og ligheder i problematiseringen og herved tydeliggøre at tilgange, der forekommer at være selvfølgelige, ikke nødvendigvis er det. Når Sverige vælges som sammenligningsland, skyldes det, at det i forhold til befolkningssammensætning, historie, kultur, sprog, økonomi og velfærdsstatens udbygning minder om Danmark, hvilket giver så ensartet sammenligningsgrundlag som muligt ${ }^{5}$. I Skandinavisk sammenhæng fremstår den danske tilgang liberalistisk, men var andre lande valgt som sammenligningsgrundlag, ville andre elementer i forebyggelsen formentlig fremstå mere iøjnefaldende (eksempelvis Albæk 2002). Den beskrivende del lægger op til en uddybning af to aspekter af forebyggelsen, som herefter diskuteres, nemlig for det første hvorfor rygning i løbet af perioden ændrer status fra at være anset som en individuel rettighed til at blive et samfundsmæssigt problem og for det andet, hvorfor denne ændring sker to årtier senere i Danmark end i Sverige.

Der er mig bekendt ikke tidligere lavet en samlet oversigt over de danske forebyggelsestiltag på rygeområdet i et længere historisk perspektiv, ligesom der ikke foreligger nogen systematisk oversigt over forebyggelsestyperne eller cigaretudgifterne.

\section{Metode}

Indsamlingen af informationer om forebyggelsesstrategierne i Danmark og Sverige er sket via systematisk litteraturstudium. Da rygeproblematikken i begge lande har ligget højt på den forebyggelsespolitiske dagsorden (eksempelvis Regeringen 2002a, Regeringen 2002b), foreligger der relativt meget materiale på området. Dette gør det systematiske litteraturstudium oplagt til at give overblik over den offentlige retorik omkring- og forebyggelsesstrategierne overfor tobaksrygningen.

Artiklens primære sigte er på de danske forebyggelsesstrategier, og der er derfor søgt i flere danske end svenske databaser, ligesom der er inkluderet flere danske end svenske publikationer i analysen. Litteratursøgningen er systematisk, idet jeg ud fra forskellige kombinationer af relevante søgeord har søgt i databaser og på hjemmesider. I engelsksproget regi har jeg altid søgt på ordene: Smoke, smoking, tobacco og cigarette ${ }^{*}$ sammensat med forskellige kombinationer af ordene: Politic*, govern*, program*, problematiz*, initiative ${ }^{*}$ og histor*. I dansk og svensk regi har jeg altid søgt på ordene: Røg/rök, ryge/röka, rygning/rökning, tobak* og cigaret* sammensat med forskellige kombinationer af ordene: Politik*, regering*, program*, problematiser*, initiativ* og histori*. 
Der er søgt i følgende databaser og hjemmesider: PubMed/Medline, WHO, Google, Sundhedsstyrelsen, Bibliotek.dk, Indenrigs- og Sundhedsministeriet, Kræftens bekæmpelse, Mandag Morgen, Retsinformation, Statens Institut for Folkesundhed, Statens Folkhälsoinstitut, Statens offentliga utredningar, register över svensk författningssamling og Bibliotek.se.

Der er indledningsvist foretaget en søgning på ovenstående søgeord. Herefter er der foretaget kædesøgninger ud fra de inkluderede teksters litteraturlister. Disse kædesøgninger fortsætter, indtil der er opnået en mætning i de publikationer, der møder kriterierne. Mætning antages ofte at være nået, når de samme udsagn gentager sig $80 \%$ af tiden (Neergaard, 2007). En specifik procentsats er svær at sætte ved litteratursøgning, men hovedtendenserne gentog sig hurtigt i langt størstedelen af publikationerne, hvorfor de sidst inddragne publikationer primært bidrager med nuancer i forhold til strategierne. Styrken ved at anvende litteraturreview som metode er, at omfanget af publikationer sandsynliggør en høj reliabilitet. Risikoen er upræcise inklusionskriterier, som kan føre til en lav validitet. Nøgleordene er imidlertid operationaliseret bredt for at højne validiteten.

Tabel 1: Klassificering af litteratur

\begin{tabular}{|c|c|c|c|c|c|c|}
\hline \multirow{5}{*}{ 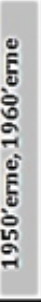 } & \begin{tabular}{|l|} 
Afsender \\
Primærlitteratur \\
\end{tabular} & Adressat & Publikationstyper & $\begin{array}{l}\text { Ant. } \\
\text { DK }\end{array}$ & $\begin{array}{l}\text { Ant. } \\
\text { SE }\end{array}$ & $\begin{array}{l}\text { Ant. } \\
\text { Int. }\end{array}$ \\
\hline & WHO & Regeringer & & - & - & 1 \\
\hline & $\begin{array}{l}\text { Regeringer, Statens Offentlige Utredningar (SE), } \\
\text { Indenrigsministeriet }\end{array}$ & $\begin{array}{l}\text { Borgere, } \\
\text { regeringer }\end{array}$ & $\begin{array}{l}\text { Love, betænkninger, } \\
\text { kampagner }\end{array}$ & 7 & 4 & 1 \\
\hline & Borgere og borgerforeninger & $\begin{array}{l}\text { Borgere, } \\
\text { regeringer }\end{array}$ & & - & 1 & - \\
\hline & Sekundærlitteratur & - & $\begin{array}{l}\text { Forskningsrapporter, } \\
\text { artikler, bøger }\end{array}$ & - & 2 & 5 \\
\hline \multirow{5}{*}{ 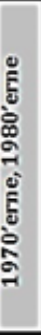 } & \begin{tabular}{|l|} 
Afsender \\
Primærlitteratur \\
\end{tabular} & Adressat & Publikationstyper & $\begin{array}{l}\text { Ant. } \\
\text { DK }\end{array}$ & \begin{tabular}{|l|} 
Ant. \\
SE
\end{tabular} & $\begin{array}{l}\text { Ant. } \\
\text { Int. }\end{array}$ \\
\hline & WHO & Regeringer & Rapporter & - & - & 1 \\
\hline & $\begin{array}{l}\text { Regeringer, Sundhedsstyrelsen, Fællesudvalget, } \\
\text { Handelsdepartementet (SE), Socialstyrelsen } \\
\text { (SE),Statens Offentliga Utredningar (SE) }\end{array}$ & $\begin{array}{l}\text { Borgere, } \\
\text { regeringer }\end{array}$ & $\begin{array}{l}\text { Love, betænkninger, } \\
\text { programmer, kampagner }\end{array}$ & 4 & 7 & - \\
\hline & Borgere og borgerforeninger & $\begin{array}{l}\text { Borgere, } \\
\text { regeringer }\end{array}$ & Artikler & 10 & 2 & - \\
\hline & Sekundærlitteratur & - & $\begin{array}{l}\text { Forskningsrapporter, } \\
\text { artikler, bøger }\end{array}$ & 2 & 1 & 2 \\
\hline \multirow{5}{*}{ 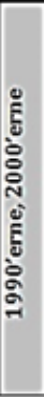 } & \begin{tabular}{|l|} 
Afsender \\
Primærlitteratur \\
\end{tabular} & Adressat & Publikationstyper & $\begin{array}{l}\text { Ant. } \\
\text { DK }\end{array}$ & \begin{tabular}{|l|} 
Ant. \\
SE
\end{tabular} & $\begin{array}{l}\text { Ant. } \\
\text { Int. }\end{array}$ \\
\hline & WHO & Regeringer & Rapporter, appendix & - & - & 14 \\
\hline & $\begin{array}{l}\text { Regeringer, Sundhedsstyrelsen, Tobaksskaderå- } \\
\text { det, Forebyggelseskommisionen, Statens } \\
\text { Institut for Folkesundhed, Statens Folkhälso- } \\
\text { institut (SE), Socialdepartementet (SE) } \\
\text { Statens Offentliga Utredningar (SE) } \\
\end{array}$ & $\begin{array}{l}\text { Borgere, } \\
\text { regeringer }\end{array}$ & $\begin{array}{l}\text { Love, rapporter, kapitler, } \\
\text { kampagner, redegørelser, } \\
\text { programmer og } \\
\text { propositioner (SE) }\end{array}$ & 28 & 23 & - \\
\hline & Borgere og borgerforeninger & $\begin{array}{l}\text { Borgere, } \\
\text { regeringer }\end{array}$ & Artikler, hjemmesider & 13 & 2 & - \\
\hline & Sekundærlitteratur & - & $\begin{array}{l}\text { Forskningsrapporter, } \\
\text { artikler, bøger, film }\end{array}$ & 27 & 9 & 9 \\
\hline
\end{tabular}


(Egen tabel. Tre af litteratursøgningens artikler er med Kræftens Bekæmpelse som eneafsender. Kræftens Bekæmpelse placeres vanskeligt $i$ én af de ovennævnte afsenderkategorier, da organisationen går på tværs af nærværende inddelinger. Af denne grund er publikationerne placeret i forhold til, hoor de hver især passer bedst, hvilket har betydet to publikationer i kategorien 'regering' og én i kategorien 'forskning'.)

Der er inkluderet 175 publikationer, der møder inklusionskriterierne ${ }^{6}$. Publikationerne kan inddeles i primærlitteratur og sekundærlitteratur. Primærlitteraturen er handlingsanvisende publikationer, der enten opfordrer til, påbyder eller forbyder en bestemt adfærd eller udtrykker befolkningens respons herpå. Den kan inddeles i tre kategorier. Den første er politiske betænkninger, love, redegørelser, programmer, rapporter, kapitler, kampagner og proportioner, der afspejler myndighedernes normative og handlingsanvisende italesættelser af og strategier i forbindelse med rygning. Den anden kategori er artikler og hjemmesider, der afspejler befolkningens reaktioner på disse italesættelser. Tredje kategori er relevante WHO rapporter, der udstikker retningslinjer for forebyggelsen. WHOs publikationer anvendes som international perspektivering, idet Danmark og Sverige blandt mange andre lande har tilsluttet sig WHOs programmer. Sekundærlitteraturen udgøres af forskningsresultater i det omfang, forskningen begrunder forebyggelsesstrategierne, samt historiske oprids af primærlitteraturen. I overensstemmelse med den induktive analysetilgang og for at undgå, at sekundære kilders tolkninger determinerer analysen, er primærlitteraturen i videst muligt omfang analyseret først. Sekundærlitteraturen bidrager imidlertid med videnskabeligt belæg for de handlingsanvisende publikationer, med opsamling af den store mængde litteratur på området og som supplement, hvor der er mangler i primærlitteraturen. I forhold til sidstnævnte gælder det især publikationer fra befolkningen, da det var vanskeligt at finde befolkningspublikationer ud over læserbreve i dagspressen, ligesom det har været vanskeligt at finde publikationer fra ikke-rygere. Der er flere publikationer i slutningen af indsamlingsperioden end i begyndelsen, hvilket formentlig skyldes, at der er skrevet mere om rygning i takt med, at rygningens skadelige virkninger bliver evidente, og rygeproblematikken i de seneste årtier placeres højt på den sundhedspolitiske dagsorden.

\section{Afgrænsning}

Jeg afgrænser mig til publikationer, der på nationalt niveau kan give indblik i normative og handlingsanvisende italesættelser af rygning. Kun publikationer, 
der adresserer eksterne aktører, er inddraget (eksempelvis fra regeringen til borgerne). Interne folketingsdebatter og arbejdspapirer er således ikke inkluderet, da debatterne er analyseret andetsteds (eksempelvis Albæk, 2002, Vallgårda 2003, Avnstrøm og Poulsen 2006). Publikationer på regionalt og kommunalt niveau er kun inkluderet såfremt samtlige regioner eller kommuner er inkluderede. Ligeledes er kilder til og fra skoler, daginstitutioner, sportshaller, arbejdspladser og hospitaler kun inkluderet, hvis der er tale om generelt materiale på landsplan, eftersom mængden af materiale ellers vil blive for omfattende. En gennemgang af udsnit af disse publikationer viser imidlertid, at ordlyden heri overordnet minder om ordlyden i de inkluderede publikationer. Endelig afgrænser jeg mig fra publikationer uden årstalsangivelse.

\section{Danske forebyggelsesstrategier sammenlignet med Sverige}

\section{0'erne og 1960'erne}

Denne periode var først og fremmest præget af en uproblematisk tilgang til tobakken. 2. Verdenskrig var stadig meget nærværende i de fleste borgeres bevidsthed, og idet flertallet af de amerikanske soldater, som mange danskere og svenskere idoliserede, var storrygere, var opfattelsen blandt majoriteten af befolkningen, at det var decideret usolidarisk at være imod tobaksrygning (Nielsen, 2000). Rygning var tilladt hvor som helst, og det var både attraktivt, stilfuldt og glamourøst at ryge. Rygeritualet ansås især i 1950'erne for at være en sofistikeret vane, som fremmede sociale relationer (Wingårdh, 1951, Griberg, 2007:59, Snowdon, 2009:132).

Hidtil havde sammenhængen mellem rygning og rygerelaterede sygdomme udelukkende beroet på spekulationer, men i 1950 publiceredes de første epidemiologiske artikler om sammenhængen mellem rygning og lungekræft (Doll and Hill, 1950:739, Wynder and Graham, 1950:329-336, Levin, Goldstein and Gerhard, 1950:336-338), og i 1952 var rygningens skadevirkninger på dagsordenen på en international kongres i Belgien (Nielsen, 2000:31, Det Nationale Råd for Folkesundhed, 2006:13). Dette blev startskuddet til, at man i USA og Europa begyndte at problematisere tobaksrygning 7 . Også i Danmark begyndte man at problematisere tobaksrygning, og i 1961 kom første betænkning om sammenhængen mellem to- 
baksrygning og lungekræft (Fællesudvalget, 1961, Indenrigsministeriet, 1964:7). Betænkningens formuleringer af sammenhængen mellem tobaksrygning og lungekræft var dog ikke entydige, og det anførtes, at "der utvivlsomt er andre faktorer, der bidrager til lungekræftens opståen" (Indenrigsministeriet, 1964:8).

På samme måde var der i Sverige usikkerhed omkring, om rygningen er så farlig, som de internationale undersøgelser konkluderede, idet man mente, at andre faktorer såsom tjærebelægninger på vejene kunne være den udløsende faktor: "Ingenting är med säkerhet känt om lungkräftans uppkomst och den förmodade ökningen kan bero enbart på ökad medellivslängd och bättre diagnostik" (Forssman och Swensson i: Torell, 2002:85). ${ }^{8}$

Dokumentationen til trods ansås rygningen i begge lande stadig, for langt de fleste rygere, for at være en relativ uproblematisk social vane snarere end en afhængighed med begrundelsen, at der ikke udvikles abstinenser ved rygeophør (Indenrigsministeriet, 1964:25), og da man endnu ikke havde opdaget problemet med den passive røg, ansås vanen i denne periode ikke for at genere rygernes omgivelser. Selvom rygningen efter 1950 formelt var anerkendt som sundhedsskadelig, blev den således stadig, i nogle år, reelt ikke italesat som et væsentligt sundhedsproblem hverken i Danmark eller i Sverige. I 1964 fremkom et udvalg i det danske Indenrigsministerium imidlertid med en udmelding, der fremstillede rygningen noget mere problematisk. Selvom der i denne udmelding både fokuseredes på det offentliges og den enkeltes ansvar for at 'omlægge rygevanerne', nævntes kun oplysningsarbejdet som et konkret muligt initiativ:

"En koncentreret indsats af alle de foranstaltninger, der kan tænkes at ville nedsætte cigaretforbruget, herunder især oplysningsvirksomhed, bør særligt have til formål at søge at afholde den opvoksende generation fra at tillægge sig de cigaretrygningsvaner, der for tiden er fremherskende i den voksne del af befolkningen. [...] Udvalget [er] af den opfattelse, at rygning normalt kun bør betragtes som en i sundhedsmæssig henseende risikabel vane, som den enkelte først og fremmest må søge at aflægge ved egen indsats" (Indenrigsministeriet, 1964:8).

Det var således borgernes eget ansvar at fralægge sig rygevanen, om det var det, man ønskede. Det danske fællesudvalg skrev i overensstemmelse hermed, at det: "[stiller] sig afvisende overfor almindelige forbud mod cigaretrygning, da man vil anse dem for nytteløse og krænkende for den personlige frihed" (Fællesudvalget, 1961:32). Allerede i oplysningsarbejdets spæde begyndelse anså Indenrigsministeriet virkningen af oplysning som værende midlertidig, hvorfor ministeriet vurderede, at oplysningsarbejdet skulle have permanent karakter. Mottoet i de første danske 
oplysningskampagner i denne periode var at: "Oplyse uden at skræmme" (Indenrigsministeriet, 1964:42).

Den første landsdækkende rygestopkampagne fra 1961 opfyldte dette kriterium. Kampagnen var henvendt til elever i folkeskolens ældste klasser ${ }^{9}$. Målet med kampagnen var ikke at afholde eleverne fra at begynde med at ryge, da dette ansås for at være usandsynligt, men i stedet at udsætte rygedebuten så længe som muligt (Sjølin et al, 1969), og appellen bestod hovedsageligt i de penge, der spares ved ikke at ryge: "Gnid øjnene grundigt og læs så denne tabel langsomt igennem. Tallene viser, hvor meget du vil eje efter 1 år eller 3 år og så videre, hvis du aldrig begynder at ryge, men i stedet sætter pengene i banken" (Clausen, 1961:12).

Selvom holdningen til tobaksrygningen i denne periode var relativt ens i Danmark og Sverige, var der også forskelle. Disse handlede ikke så meget om synet på tobakken som om synet på samfundets og borgerens ansvar i forhold til tobaksproblemet. Allerede i 1950'erne og 1960'erne var der i Sverige større fokus på at indrette samfundsstrukturerne, så det blev lettere ikke at ryge. Eksempelvis eksisterede der siden 1956 offentligt finansierede tobaksafvænningsklinikker i Stockholm ${ }^{10}$. Ligeledes indførtes i 1969, flere årtier før der i Danmark blev foretaget strukturorienterede strategier, restriktioner i forhold til tobaksreklamer således, at reklamerne ikke måtte fremkalde associationer til helse og sundhed. Indtil da havde disse associationer været almindelige i reklamerne. Kort efter blev det besluttet, at der heller ikke måtte være mennesker i tobaksreklamerne, da tobakken ikke måtte associeres med noget positivt overhovedet: "En säker utväg att undgå berörda risk för olämplig verkan av bildmaterial i cigaretreklamens tjänst synes vara att dylikt material inskränks till att mot neutral bakgrund uppvisa varan som sådan, dvs. cigarettpaket eller cigaretterna" (Marknadsdomstolens avgöranden, 1971-1973 i:Torell, 2002:188).

Endnu en forskel på landene var, at der var meget få tobaksreklamer i Sverige i 1950'erne, da markedet kontrolleredes af Aktiebolaget Svenska Tobaksmonopolet (Rimpelä, 1977:76). Da der var monopol på cigaretterne, var der ingen grund til at reklamere for dem, hvilket kan have været medvirkende til, at andelen af rygere var lavere end i Danmark. I 1957 ophørte monopolet, og der var herefter omtrent lige så mange tobaksreklamer i Sverige som i Danmark. Denne udvikling fulgtes op af en betydelig stigning i andelen af daglige rygere i Sverige i 1960'erne og 1970'erne (figur 1). 


\section{0'erne og 1980'erne}

Der var i den danske og svenske rygepolitiks spæde begyndelse i 1950'erne og 1960'erne ikke nogen ensretning af rygepolitikken på tværs af landene. Dette ændrede sig formelt i 1971, da WHO introducerede et program, der opfordrede medlemslandene til at: Oprette institutioner til bekæmpelse af rygning, undersøge rygningens omfang, forbyde tobaksreklamer, forhøje tobaksafgifterne, undervise om rygningens skadelige virkninger og forbyde rygning i alle offentlige lokaler (Nielsen og Nygaard, 1982:27). Både Danmark og Sverige tilsluttede sig erklæringen. Det nye ved erklæringen var, især i forhold til den danske rygepolitik, at hovedparten af WHOs retningslinjer var af strukturel karakter. WHO begrundede i et senere program, gengivet på dansk af Tobaksskaderådet, hvorfor man mente, det var vigtigt både at lave politikker på det individuelle og det strukturelle niveau og ikke primært forlade sig på oplysningskampagner:

"Tobaksproblemet er så alvorligt og komplekst, at oplysning alene kun har haft ringe virkning. De enkelte lande må derfor ikke alene forlade sig på oplysning som løsningsmodel, men fastlægge en tobakspolitik, der gør det lettere at beslutte ikke at ryge. Dette skal ske ved en påvirkning af de kulturelle, sociale og økonomiske faktorer, der har indflydelse på såvel enkeltpersoners som gruppers tobaksforbrug. [...] De lande, der har haft størst succes med at kontrollere tobaksforbruget på lang sigt, har haft en tobakspolitik, som harmoniserede og koordinerede et bredt spektrum af kollektive og individuelle foranstaltninger"(WHO i:Tobaksskaderådet, 1989:15).

I overensstemmelse med WHOs målsætninger iværksattes fra midten af 1980'erne og frem de første strukturorienterede strategier for at regulere tobaksrygningen i Danmark. Blandt andet indførtes i 1986 lov om, at indholdsdeklarationerne skulle stå synligt på tobakspakkerne, og i 1988 indførtes lov om sikring af røgfrie miljøer blandt andet i statslige lokaler og transportmidler (Regeringen, 1989:49). Den primære forebyggelsesstrategi var dog stadig oplysningskampagner orienteret mod 'den enkeltes ansvar for egen sundhed', som fra denne periode og frem nærmest blev et mantra i den danske forebyggelse. Udfordringen var at få borgerne til selv at identificere sig med dette mantra. I 1977 skrev Prioriteringsudvalget, at der "i hele befolkningen [burde] skabes en større forståelse for eget ansvar - og betydningen af egen indsats - for helbredstilstanden" (Prioriteringsudvalget i Sundhedsvæsenet, 1977 i: Vallgårda, 2003:148). Denne italesættelse af ansvarsplaceringen blev gentaget i regeringens forebyggelsesprogram fra 1989: 
"For mange gælder det, at de ofte er mere indstillet på at leve med de sundhedsrisici, som man selv har indflydelse på, end de skadelige påvirkninger, der kommer udefra. Balancen mellem samfundets indsats og den enkeltes egen indsats for sin sundhed er blevet skæv - på nogle områder urimeligt skæv. Dette er en væsentlig baggrund for forebyggelsesprogrammets prioriteter og valg af indsatser" (Regeringen, 1989:8).

I 1987 etablerede regeringen og Sundhedsstyrelsen et statsligt, uafhængigt og sagkyndigt tobaksskaderåd ${ }^{11}$, hvis primære formål var at oplyse og rådgive om tobaksrygning (Avnstrøm og Poulsen, 2006:38), og rådet iværksatte kampagnerne: "Røgfri årgang" og "Giv røgen en pause" (Døllner, 1989, Nielsen, 2000:35). Retorikken vedrørende rygningens skadelige virkninger var dog stadig afdæmpet i denne periode, og det var vigtigt for regeringen, at oplysningskampagnerne ikke måtte virke intolerante overfor dem, der ikke ønskede eller ikke magtede et rygestop (Regeringen, 1989:14).

Hvor synet på rygning i Danmark i 1970'erne og 1980'erne var meget lig tiårene tidligere, ændrede tobaksrygningen markant status i Sverige i denne periode. Hvor rygningen i 1970'erne stadig associeredes med frihed og socialt samvær, associeredes det i den offentlige debat fra 1980'erne og frem med sygdom og død (Svenska läkartidningen, 1982, Torell, 2002:172). Den udløsende faktor til dette holdningsskifte var dels internationale forskningsresultater, der introducerede begrebet 'passiv rygning'12 i 1981 (Hirayama, 1981, Torell, 2002:215, Larsen 2008:760) og dels internationale antirygebevægelsers krav om røgfrie miljøer, som man henviste til i den svenske debat (Torell, 2002:172, Snowdon, 2009:144-145). Det blev nu evident, at rygning ikke kun var sundhedsskadelig for rygerne selv, men også for deres omgivelser. I tiden inden blev passiv rygning opfattet som en irriterende - men ikke sundhedsskadelig - gene (Avnstrøm og Poulsen, 2006:35, Larsen, 2008:764). Når borgernes frihed til at ryge gik ud over andre borgeres sundhed, intensiveredes de forebyggelsespolitiske strategier ${ }^{13}$, og rygernes status ændredes markant, idet rygning gik fra at blive set som en social begivenhed og en vane til at blive karakteriseret som en sygdom ${ }^{14}$. Svenska läkartidningen skriver herom:

\footnotetext{
"Vanerökaren kan helt sakna symptom men har på många sätt en rubbad fysiologisk balans. Många laboratorievärden är förskjutna och fler läkemedel metaboliseras annorlunda. Prognosen är ordentligt ogynnsam. Det är inkonsekvent att undanta nikotinism när andra beroendetillstånd som alkoholism och narkomani klassas som sjukdomar" (Svenska läkartidningen, 1982:1115).
} 
Med ét slag blev rygeafhængighed en sygdom, som kunne sammenlignes med alkoholisme og narkomani, og en tredjedel af alle svenskere blev herved sygeliggjorte! $!^{15}$ (SOU, 2000, Torell, 2002:210, 297). Tobaksrygningen var nu ikke længere et socialt fænomen, men blev problematiseret som et medicinsk og samfundsmæssigt problem. Retorikken omkring det sociale aspekt af tobaksrygningen blev således fuldstændig vendt på hovedet i forhold til 1950'erne og 1960'erne. I 1980'erne gik argumenterne for at stoppe med at ryge på, at: "Man blir mer socialt accepterad. Minoriteten rökare uppfattas alltmer som störande element på jobbet och $i$ vänkretsen. Man blir kort sagt lättare omtyckt" (Vecko Revyn, 1985 i: Torell, 2002:211). I 1950'erne og 1960'erne brugtes selvsamme argumenter i tobaksrygningens forsvar (Torell, 2002).

I modsætning til opfattelsen i Danmark, ansås rygning i Sverige ikke for at være et problem, man kunne oplyse sig ud af. I stedet var der fokus på de sociale faktorer, som havde betydning for, om man begyndte at ryge eller ej. Socialstyrelsens tobaksutredning skrev herom:

"För barn framstår rökningen som en del av den vuxnes (och numera även ungdomens) värld. Ren nyfikenhet och drift att härma medför lust att komma i kontakt med den världen och att pröve dess vanor. Rökningen är vidare ett medlet att komma i en grupp och känna gemenskap med denna - under förutsättning att rökning är vanlig i den. När ungdomsgrupper röker, har barn som vill bli upptagna i dem ett motiv att röka" (Socialstyrelsens Tobaksutredning, 1973:59).

Problematiseringen af den passive rygning, først i Sverige og senere i Danmark indebærer et skifte fra opfattelsen af, at tobaksrygningen kun var sundhedsskadelig for rygerne til, at den også skadede omgivelserne. Idet det problematiseres, at borgerens frihed til at ryge ikke kun går ud over eget helbred, men også risikerer at begrænse omgivelsernes frihed til at leve et sundt liv, skærpes de politiske styringsambitioner kraftigt. Selvom styringsambitionerne i den svenske rygepolitik øgedes i 1980'erne, ændrede det ikke på, at samfundets ansvar oftere blev italesat end borgerens (Rimpelä, 1977:76). Tværtimod havde staten med rygeafhængighedens nye status som sygdom et endnu større ansvar.

\section{0'erne og 2000'erne}

Som beskrevet ovenover var tobaksrygning ikke højt på den sundhedspolitiske dagsorden i Danmark i 1970'erne og 1980'erne. Dette var imidlertid stilhed før storm, for i 1990'erne og i 2000'erne accelererede tiltagene. I 1991 vedtog regerin- 
gen en ny tobakslov, der blandt andet påbød advarselstekster på alle tobaksvarer. Samtidig iværksattes kampagnen: "Når pædagogikken ryger", som henvendte sig til nøglepersoner på skolerne. I 1994 iværksattes rygestopkurser for udvalgte patientog befolkningsgrupper samt visse ansatte (Kræftens Bekæmpelse, 2001). I 1995 kom endnu en lov om røgfrie miljøer blandt andet i offentlige lokaler og transportmidler, og der kom endnu en rygestopkampagne: "STOP"-kampagnen ${ }^{16}$. I 2001 blev rygning i folkeskolerne forbudt for eleverne, og i 2002 opdateredes rygeloven endnu engang, idet der, via et EU-direktiv, kom forbud mod tobaksreklamer og tobakssponsorater ${ }^{17}$. Der indførtes grænseværdier for indholdsstofferne i cigaretter, salg af tobaksvarer til børn blev forbudt, og i 2003 besluttedes det at forstørre advarselsteksterne. Endelig iværksattes i 2004 kampagnen: "Sig nej til tobaksforurenet luft" (Sundhedsstyrelsen, 2004).

Også en del videnskabelige undersøgelser bliver i denne periode inddraget $\mathrm{i}$ den offentlige rygedebat i større omfang end tidligere. Blandt andet udkom middellevetidsrapporten fra 1994. Rapporten fastsætter rygning som den væsentligste årsag til stagneringen i den danske middellevetid i 1980'erne og 1990'erne og et fald i placeringen fra femte højeste middellevetid blandt OECD landene i 1970'erne til nummer 55 i 1990'erne, en udvikling, som ikke sås i andre vestlige lande (Sundhedsministeriets Middellevetidsudvalg, 1994, Albæk, 2004:33). Desuden satte Arbejdsmiljøinstituttets rapport fra 2004 passiv rygning i arbejdsmiljøsammenhæng $^{18}$ (Borg, 2004) og i 2005 udkom hvidbogen om passiv rygning (Clemmensen et al, 2005). Der har også tidligere været publiceret videnskabeligt materiale om rygningens skadelige virkninger, uden at det af den grund er kommet højt på dagsordenen hos politikerne eller befolkningen, men som flere publikationer kommer til, bliver evidensen herfor så vægtig, at den ikke længere kan ignoreres.

Stramningerne blev imødegået af utilfredshed blandt nogle borgere. Det var især kunstnere, forfattere, musikere og visse subkulturer, der var på banen (Eksempelvis Stobbe, 1993:61). Det, der kendetegnede hovedparten af publikationerne med befolkningen som afsendere var, at man anså tiltagene for at være formynderiske og en indskrænkelse af den personlige frihed. Et mærkat, der ikke i nær samme grad blev sat på de svenske tiltag til trods for, at mange danskere netop anså svenskerne for at være underlagte formynderi.

Selvom styringsambitionerne øgedes markant i begge lande, først i Sverige og herefter i Danmark, idet rygning kom højt på den politiske dagsorden, ændrede det ikke på, at rygning i Danmark stadig primært opfattedes som et individuelt problem, og at løsningen på problemet stadig var borgerens ansvar. Denne opfattelse stemmer overens med mere generelle politiske strømninger, som eksempel- 
vis regeringens folkesundhedsprogram fra 2002: "Afgørende er, at den enkeltes selvbestemmelse respekteres. Det offentlige skal ikke styre vores liv. Den enkelte har et ansvar - for sig selv, sine nærmeste og fællesskaberne" (Regeringen, 2002b:57).

Nærmest i direkte modsætning til dette skrev den svenske regering samme år i sit folkesundhedsprogram, at samfundet har et ansvar for at: "skapa samhälleliga forutsättningar för en god hälsa på lika villkor" (Regeringen, 2002a:27). Den svenske regering skrev videre: "Eftersom skillnaderna följer mycket tydliga sociala mönster, så beror inte olikheterna i hälsa främst på individernas medvetna val av livsstil [men også på] låg lönn, dålig arbetsmiljö, liten frihet $i$ arbetet, ekonomisk stress, dålig boendestandard och begränsade möjligheter till semesterresor, rekreation, kultur ect." (Regeringen, 2002a:3536). I overensstemmelse hermed skrev den svenske Folkhälsokommittéen:

"Ny kunskap visar att bruket av tobak är inte följden av ett fritt konsumtionsval, utan tobak är i stället en drog med snabb tillvänjning [...] Tobaksbruk bör därför ses ur ett drogpolitisk perspektiv och inte som vilken konsumtionsvara som helst. [Derfor er det også] ett ansvar för samhället att hjälpa dem som vill sluta röka" (SOU, 2000 i: Vallgårda, 2003:150).

Hvor de danske tiltag for at mindske rygningen accelererede i 1990'erne og 2000'erne, kan de svenske tiltag bedst betegnes ved, at de fulgte det spor, som blev udstukket i årtierne tidligere ${ }^{19}$. I 1993 indførtes en omfattende rygelov, som blandt andet forbød tobaksreklamer, højnede afgifterne på tobak og indførte restriktioner på rygning inden døre. Loven var resultat af en omfattende debat og en række betænkninger i 1980'erne, og dens strukturelle fokus stemte godt overens med den orientering mod samfundets ansvar, som også i disse tiår prægede den svenske tobakspolitik. Ansvaret formuleredes: "entydigt som en offentlig och samhällelig angelägenhet" (Lindgren, 1993 i: Torell, 2002:255). Der var dog også fokus på individorienterede strategier og kampagner i 1990'erne, eksempelvis "Våldtagen av en Prince" fra 1994 og "Welcome to Marlboro Country" fra 1997.

Fra midten af 2000'erne og frem indføres en række strukturorienterede tiltag i Danmark. I 2007 indførte regeringen en rygelov vedrørende ufrivillig udsættelse for passiv rygning, som forbyder rygning inden døre i det offentlige rum ${ }^{20}$ (Folketinget 2007). Loven er en væsentlig stramning i forhold til tidligere, og igen blev den mødt af markant kritik fra rygerne, især i visse subkulturer.

Figur 2: Udvikling i afgifter på cigaretter, Danmark 


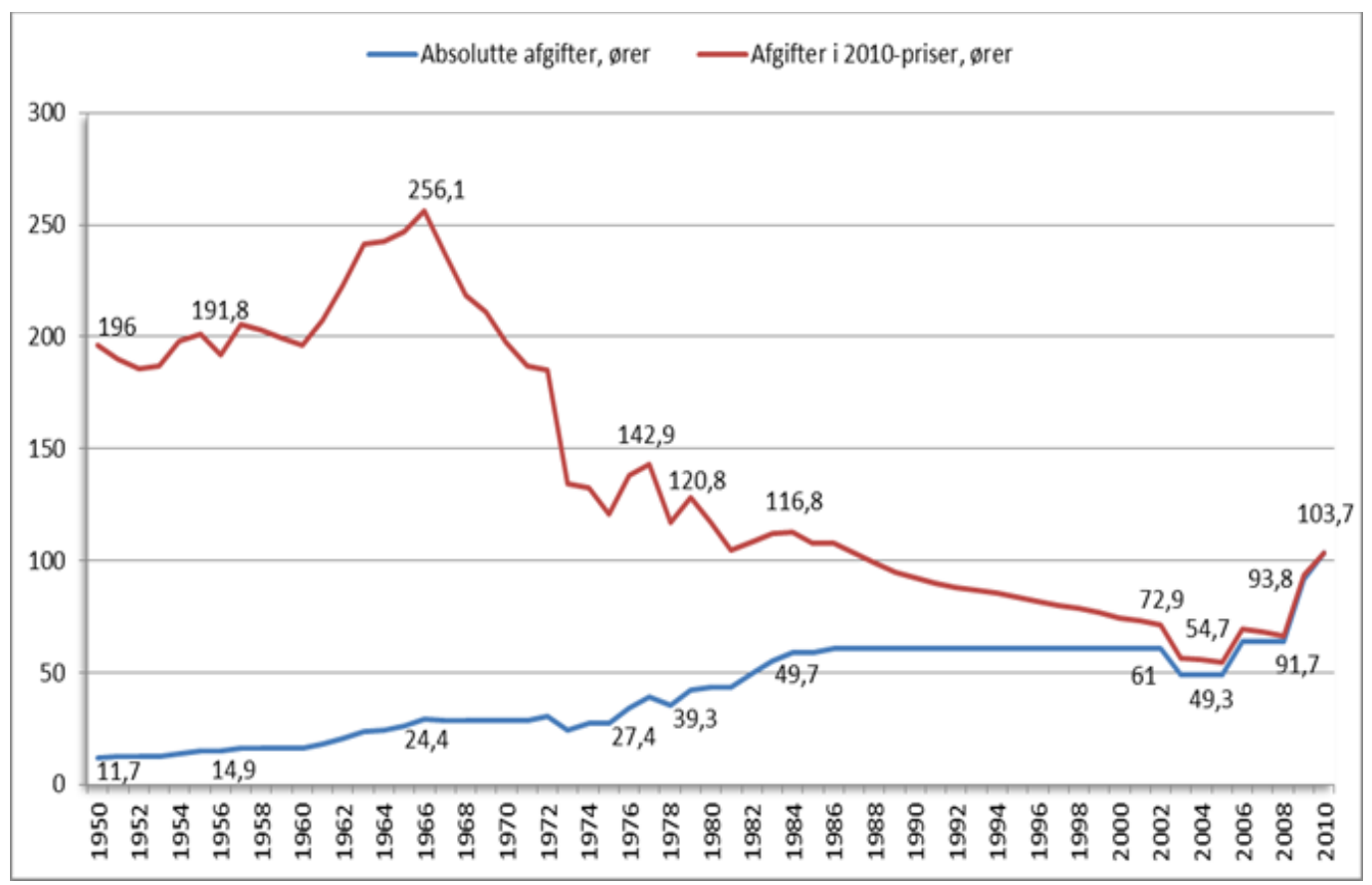

(Egen figur på baggrund af Bardenfleth og Madsen 2000 og Danmarks Statistik, dst.dk)

I 2006 og 2009 forhøjedes afgiften på tobaksvarer ${ }^{21}$. Det var dog først med afgiftsstigningen og indførelsen af en minimumsafgift i 2009, at borgernes sundhed blev angivet som årsagen til afgiften ${ }^{22}$. I tiden forinden var argumentet flere penge i statskassen. Afgiftsstigningen kan dog langt fra kompensere for, at en stigning i købekraften løbende har udhulet effekten af tobaksafgifterne, og i 2003 sættes afgiften reelt ned med begrundelsen at mindske grænsehandlen (Albæk, 2004:1617). Den absolutte og relative tobaksafgift fremgår af figur 2 , hvor opgørelser fra Danmarks statistiks Forbrugerprisindeks og Dansk Tobaksindustri er sammenholdt. Afgifterne i 2010-priser er udregnet via Danmarks Statistiks inflationsberegner (dst.dk) $)^{23}$.

Iværksættelsen af flere strukturorienterede tiltag i Danmark i 2000'ernes er imidlertid ikke ensbetydende med, at det individuelle fokus mindskes i perioden. Der satses stadig markant på oplysningskampagner, som kampagnen: "Hver eneste cigaret skader dig" (Sundhedsstyrelsen, 2009) ${ }^{24}$. Med denne kampagne bevæger Sundhedsstyrelsen sig væk fra det tidligere mantra om at 'oplyse uden at skræmme' og følger i stedet kursen fra blandt andet Sverige, hvor retorikken i oplysningskampagnerne siden 1994 har haft karakter af skræmmekampagner.

Figur 3: Tidslinje over tiltag for at begrænse rygning i Danmark og Sverige 


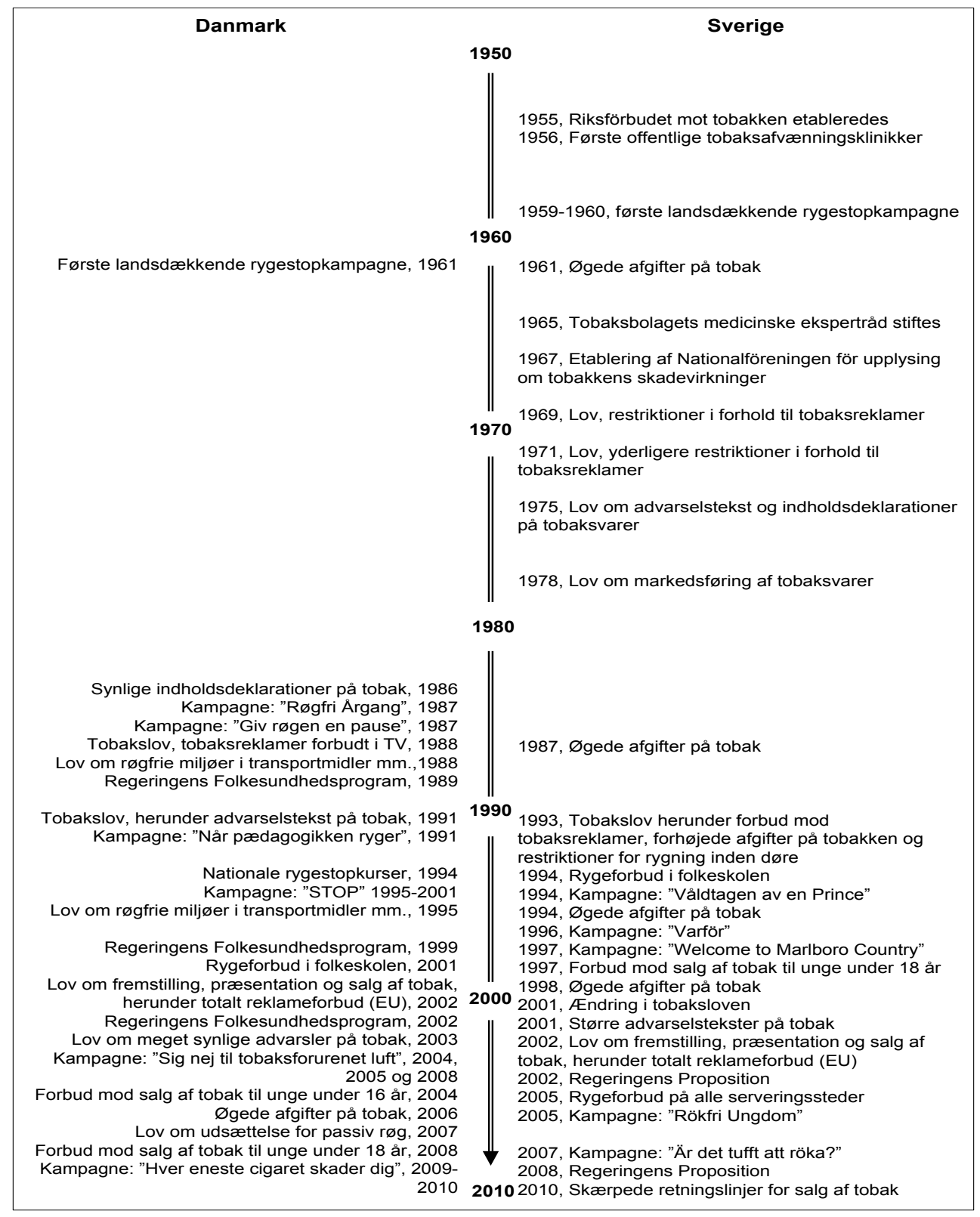

(Egen figur. Jeg har afgrænset mig til indførte tiltag, og har således udeladt høringer, cirkulærer, betænkninger og ikke-vedtagne forebyggelsesforslag, da omfanget heraf er relativt stort.) 
På baggrund af den historiske gennemgang diskuteres i nedenstående to afsnit dels, hvorfor der gik så lang tid, inden rygningen adresseredes som et samfundsmæssigt problem, hvorfor dette skete netop i 2000'erne, og hvorfor skiftet skete senere i Danmark end i Sverige.

\section{Fra individuel rettighed til samfundsmæssigt problem - når rettigheder dræber}

Det fremgår af den ovenstående beskrivelse, at der siden 1950 har været videnskabeligt belæg for rygningens skadevirkninger, men først et halvt århundrede senere, i 2000'erne problematiseres rygningen i Danmark for alvor som et samfundsmæssigt problem, der kræver strukturorienterede løsninger ${ }^{25}$. Dette fordrer spørgsmålene: Hvorfor gik der så lang tid, og hvorfor ændredes strategierne netop i 2000'erne?

Svaret på begge spørgsmål skal findes i 'opdagelsen' af den passive rygning i 1981 (Hirayama, 1981) og hermed et ændret syn på tobakken, idet det bliver evident, at rygningens skadelige virkninger ikke blot går ud over rygeren selv, men også skader vedkommendes omgivelser. Til trods for, at der skulle gå 26 år, inden udsættelse for passiv røg på offentlige steder blev forbudt ved lov (lov nr. 512 af 06/06/2007), har rygning oftere været på den politiske og forskningsmæssige dagsorden efter opdagelsen af passiv rygning end inden. Det var dog kun røgfrie miljøer på offentlige arbejdspladser og i transportmidler, der diskuteredes i 1980'erne og 1990'erne (Avnstrøm og Poulsen, 2006:33). Dokumentationen af den passive røgs skadelige virkninger medførte det samfundsmæssige problem, at én borgers rettighed til frit at ryge krænker en anden borgers rettighed til sundhed. Rygeres og ikke-rygeres rettigheder er således uforenelige, og der må træffes et valg omkring, om det er rygerens eller ikke-rygerens rettigheder, der skal sikres (Gostin, 1997:334,345-352, Snowdon, 2009:132-133). WHO skriver allerede i resolutionen fra 1986, at rygning er uforenelig med sundhed, og at det er et statsligt ansvar at beskytte ikke-rygeren mod skadelig tobaksluft (WHO, 1986).

Den danske stat påtager sig da også et vist ansvar i 1980'erne og 1990'erne, men i denne periode udmøntes ansvaret ikke i gennemgribende lovgivning om afgifter og røgfri miljøer, som WHO-anbefalingerne ellers går på, da dette af mange anses for at overskride statens ret og pligt. Argumentet er, at rygning er en privat sag, og at lovgivning vil krænke den personlige frihed (Regeringen, 2002b, Avnstrøm 
og Poulsen, 2006:2,34). Problemet med den passive rygning fremstilles således i disse årtier primært som et internt problem mellem rygerne og ikke-rygerne, idet rygerne opfordres til at udvise mere hensyn. Eksempler på dette er det tidligere inddragne citat fra den danske regerings folkesundhedsprogram: "Afgørende er, at den enkeltes selvbestemmelse respekteres. Det offentlige skal ikke styre vores liv" (Regeringen, 2002b:57). Her beskrives individets selvbestemmelse og frie valg i et modsætningsforhold til statens normative retningslinjer om sund livsstil. I overensstemmelse med denne tilgang oprettedes i 1987 foreningen Hen-Ry, som var en sammenslutning af 'hensynsfulde rygere'26 (Albæk, 2004:4), ligesom der blev lavet en række frivillige aftaler på lokalt niveau, eksempelvis på arbejdspladser.

WHO skriver om denne danske tilgang, at: "Mange danske politikere, fra venstreorienterede til højreorienterede, beskrev deres politik - ofte eksplicit i modsætning til Sverige-som værende orienteret mod individuel frihed, hvor borgerne behandles som voksne mennesker, der kan tage ansvar for deres egen sundhed med et minimum af indblanding fra staten" (Hogsted et al., 2008:67, egen oversættelse). Ud fra denne optik ligger både årsagen til og løsningen på befolkningens sundhedsproblemer først og fremmest hos borgeren selv og i dette tilfælde hos rygerne. Eftersom ansvaret for problemet med den passive røg i denne periode pålægges rygerne, består statens rolle i at oplyse om rygningens skadevirkninger som et værktøj til at holdningspåvirke rygerne til at stoppe med at ryge eller i det mindste at udvise større hensyn, når de ryger. Kompromiset bliver indførelsen af såkaldte 'hensynslove', som tilskynder rygerne at udvise hensyn, når de ryger i for eksempel offentlige transportmidler (Avnstrøm og Poulsen, 2006:36-37,43).

Først da passiv rygning med Arbejdsmiljøinstituttets rapport "Passiv Rygning" fra 2004 (Borg, 2004) italesættes som et arbejdsmiljøproblem på linje med andre giftige stoffer på arbejdspladserne, ændres problemidentifikationen for alvor, og det anses nu for uetisk, at arbejdstageren påføres en sundhedsrisiko ved at udføre sit arbejde. I denne sammenhæng bliver det tydeligt, at sundhed ikke kun er betinget af borgerens egne livsstilsvalg, men også af de samfundsmæssige rammer, borgeren indgår i, og som er udenfor vedkommendes egen kontrol. Med denne kontekstualisering ændres opfattelsen af rygning og passiv rygning fra at være et internt problem mellem borgerne til at blive et samfundsmæssigt problem. "Statslig intervention synes ikke længere at virke så truende som i 1980'erne og i perioden etableredes der konsensus blandt de politiske aktører om, at staten har et medansvar for løsningen af problemet med passiv rygning" (Avnstrøm og Poulsen, 2006:49). Fra midten af 2000'erne begynder italesættelsen af borgernes rettigheder således at tage en ny form, da ikke-rygerens ret til sundhed og tobaksfri luft fra denne periode oftere 
og oftere italesættes fremfor rygerens ret til frit at ryge. Betegnelser, som at 'det er en menneskeret at være fri for røg', konstruerer en forestilling om, at borgerens grundlæggende rettigheder krænkes, når vedkommende udsættes for passiv røg, og eftersom beskyttelse af menneskerettigheder anses for at være en universel værdi, staten må sikre borgerne, er statslig indblanding nu blevet indiskutabel.

Dette skifte stemmer overens med filosoffen John Stuart Mills liberale grundtanke, at borgernes handlefrihed kun må begrænses for at sikre andre borgeres frihed (Mill 1859:9). Mill skelnede mellem handlinger, der vedrører borgerne selv og handlinger, der også influerer andre ${ }^{27}$. Med 'opdagelsen' af passiv rygning skifter opfattelsen af rygehandlingen regi fra at være en handling, der udelukkende skader den rygende borger selv til at blive opfattet som en handling, der også skader andre. Herved bliver rygeproblematikken et samfundsmæssigt problem, der påkræver sig politisk styring.

\section{Dansk inerti}

Den historiske oversigt fordrer også et andet spørgsmål, nemlig hvorfor den danske tilgang er præget af inerti ${ }^{28} \mathrm{i}$ forhold til den svenske tilgang. Sverige reagerer langt hurtigere på den epidemiologiske forsknings evidens og adresserer rygning som et samfundsmæssigt problem to årtier tidligere end Danmark. Især tre barrierer ser ud til at spille ind i forhold til denne træghed, nemlig synet på rygningen, forskningens vilkår i offentligheden og de to landes forskellige identitetsopfattelser.

\section{Synet på rygning}

Allerede i 1982, ét år efter 'opdagelsen' af passiv rygning, klassificeres rygning i Sverige som en sygdom på linje med alkoholisme og narkomani (Torell, 2002:210). Herimod fremstilles rygning i Danmark i hele undersøgelsesperioden oftest som usund livsstil. Forskellene i fremstillingen kan have stor betydning for, hvordan og af hvem rygeproblemet skal løses, idet de fleste vil være enige i, at samfundet har et større ansvar for at løse borgernes sygdomsproblemer end deres usunde livsstil. Indlejret i beskrivelsen af rygning som en sygdom ligger også associationen, at rygning ikke udelukkende er et frit valg, som borgerne træffer på et oplyst grundlag. I stedet beskrives borgerenes handlinger som afhængige og påvirkelige af den kontekst, borgeren agerer i. Dette så vi blandt andet i citatet fra den sven- 
ske regerings folkesundhedsprogram, der beskriver, at samfundet har et ansvar for at: "skapa samhälleliga forutsättningar för en god hälsa på lika villkor" (Regeringen, 2002a:27). Denne tilgang stemmer godt overens med WHOs definitioner. I WHOs Ottawa Charter fra $1986^{29}$ (WHO, 1986) italesættes, at borgerne i forhold til egen sundhed ikke altid er frie, men påvirkes af de relationer og det samfund, de indgår i. Eksempelvis påvirkes borgerne af tobaksindustriens reklamer og lobbyarbejde. Fokus har derfor været på at indrette omgivelserne, så det sunde valg bliver det lette valg (WHO, 1986). WHO har siden 1971 anbefalet en stærk forebyggende indsats, både på det individuelle og det strukturelle niveau og uddyber: "Tiltag, som kun håndterer adfærd, vil have begrænset succes; de søger mikroorienterede løsninger på et problem på makroniveau" (Crombie et al., 2005:5, egen oversættelse).

Når rygning beskrives som en samfundsskabt sygdom, som påvirkes af magtstrukturer på makroniveau, eksempelvis af tobaksindustrien og modetendenser, som ligger udenfor borgerens indflydelse, bliver det mere legitimt for staten at intervenere mod det, end hvis rygning beskrives som en livsstil, som det ofte er tilfældet i Danmark, idet livsstilsbegrebet lægger op til fokus på mikroniveau - på borgerens valg.

\section{Forskningens vilkår i offentligheden}

En anden barriere er, at det i dansk sammenhæng hører til sjældenhederne, at forskningsresultater øver en direkte indflydelse på politisk-administrative beslutninger (Albæk, 2004:87). Til trods for, at der allerede fra 1950 forelå dokumentation for rygningens skadevirkninger og i 1964 var publiceret mere end 7.000 internationale videnskabelige artikler herom (Surgeon General, 1964) og til trods for evidens for den passive rygnings skadevirkninger fra 1981, var det kun meget få politikerne, der i de første tiår af litteraturstudiet refererede til videnskabelig dokumentation (Avnstrøm og Poulsen, 2006:57). Først op gennem 1990'erne og 2000'erne, hvor det videnskabelige belæg for passiv rygnings skadevirkninger bliver entydigt og massivt dokumenteret i en lang række videnskabelige publikationer, og herved bliver alment accepteret viden blandt en række centrale aktører, bliver forebyggelsesstrategier begrundet i epidemiologisk forskning. Indflydelsen foregår således ikke lineært, men via borgerne og forskellige meningsdannere. I Sverige ses der en mere direkte forbindelse mellem forskningsresultater og holdningsændringer, hvilket hænger sammen med, at populærmedier hurtigere tog rygeproblematikken op i Sverige (Torell, 2002). 


\section{Friheds-Danmark og Forbuds-Sverige}

Endelig kan den danske modvilje mod at implementere strukturorienterede strategier forklares i danskernes selvforståelse. Det går igen i en lang række af litteraturstudiets publikationer, uanset om afsenderen er staten eller befolkningen, at staten ikke skal styre borgernes liv med påbud og forbud. Flere steder begrundes dette i den danske mentalitet, hvor danske borgere beskrives som 'noget særligt', som frihedselskende og derfor som modstandere af tvang (Vallgårda, 2003:266). WHOs retningslinjer om strukturel forebyggelse, som går helt tilbage til 1971, har således svære vilkår i Danmark, eftersom de ikke er forenelige med opfattelsen af 'frihedsDanmark'. I danske publikationer refereres der, indtil 1980'erne ofte til 'forbudsSverige' som skræmmebillede og som eksempel på et samfund, hvor der styres via formynderi og forbud. Skræmmebilledet ændres dog i 1990'erne og 2000'erne i stedet til et forbillede i takt med at flere strukturorienterede tiltag indføres i Danmark. Selvbilledet er noget anderledes i Sverige, idet opfattelsen er, at svenskerne er 'de bedste' blandt andet på grund af en høj middellevetid sammenlignet med blandt andet Danmark (Vallgårda, 2003:266). Dette selvsikre selvbillede og stræben efter at være bedst har formentlig bevirket, at man med målet om en sund befolkning for øje har været mere villige til at acceptere strukturorienterede strategier.

\section{Konklusion}

Det fremgår af litteraturstudiet, at Danmark kom væsentligt senere i gang med forebyggelsestiltag for at mindske rygningen end Sverige. Fra midten af 1980'erne og frem blev styringsambitionerne imidlertid større, og et væld af tiltag iværksattes. I 1980'erne og 1990'erne er de danske tiltag primært rettet mod individets ansvar for at leve sundt, og strukturelle forebyggelsesstrategier er i denne periode af mindre intervenerende art. I 2000'erne ændres denne tendens, idet de strukturorienterede tiltag bliver mere ambitiøse. Til sammenligning starter Sverige ud med primært ud med strukturorienterede strategier, hvorimod kampagner bliver mere hyppige tiltag i 2000'erne. Først med den passive rygnings problematisering på den sundhedspolitiske dagsorden i 2000'erne adresseres rygning som et samfundsmæssigt problem, der kræver strukturelle løsninger, idet rygerens frihed til at ryge bliver uforenelig med ikke rygerens ret til sundhed. 


\section{Noter}

1 Prævalenserne dækker over store forskelle mellem andelen mandlige og kvindelige rygere.

2 'Borgerne' definerer jeg som civile borgere, som ikke repræsenterer formelle politiske eller økonomiske systemer.

3 Med 'samfundet' menes de statslige institutioner med relevans for folkesundheden, især regeringen, sundhedsstyrelsen, sundhedsministeriet og andre institutioner, der har indflydelse på sundhed, sygdom og forebyggelse.

4 Med 'problematiseres' menes hvorfor det fremstilles som et problem, hvem det er et problem for samt hvilke årsager og løsninger, der identificeres.

5 Der er dog en del historiske og kulturelle forskelle, som betyder, at svenske forebyggelsestiltag ikke uden videre kan overføres til Danmark, idet de enkelte tiltag ikke kan ses isoleret fra den kontekst, de er en del af (Vallgårda og Koch, 2007:233). Eksempelvis adskiller lovgivningsprocesserne i Sverige sig fra Danmark ved, at de oftere bliver til på baggrund af omfattende betænkninger, høringer og begrundelser, end det er tilfældet i Danmark (Vallgårda, 2003:23-24).

6 Søgningen på de inkluderede søgeord gav flere end 175 publikationer. De 175 publikationer er inkluderet, fordi de både møder inklusionskriterierne og vurderes at være relevante for artiklens sigte.

7 Eksempelvis i: "Smoking and Health: A report of the Royal College of Physicians of London on smoking in relation to cancer of the lung and other diseases" (Horn, 1962), "Cigarette smoking and health: A review of studies by the California State Department of Public Health; a summary of opinion; a proposal for action" (California Department of Public Health, 1963), "Prevention of Cancer" (WHO 1964) samt "The 1964 Report on Smoking and Health" publiceret af den amerikanske Surgeon General, som finder evidens for, at tobaksrygning og ikke eksempelvis luftforurening er den primære årsag til lungekræft (Surgeon General, 1964).

8 På linje med de danske og svenske publikationer vurderede også mange internationale publikationer i denne periode rygningens sundhedsskadelige virkninger på linje med andre formodede skadelige faktorer som eksempelvis luftforurening (Gostin, 1997:347).

9 Kampagnen udgjordes af en kombination af plakater, brochurer og en kort oplysningsvideo til skoleeleverne (Indenrigsministeriet, 1964:41).

10 Der har i 1959 været en tilsvarende klinik på forsøgsbasis i København, men på grund af manglende økonomisk støtte eksisterede klinikken kun i et år (Indenrigsministeriet, 1964:26).

11 Det danske Tobaksskaderåd blev etableret efter norsk forbillede.

12 Problematikken omkring den passive røg blev opdaget ved omfattende undersøgelser af ikke-rygende kvinder, der var gift med mænd, der røg. Undersøgelserne viste, at disse kvinder havde øget risiko for cancer og hjertekarsygdomme i forhold til ikkerygende kvinder, der var gift med ikke-rygende mænd (Hirayama). I 1986 anerkendte blandt andre The International Agency for Research on Cancer og amerikanske Surgeon General officielt sammenhængen mellem pasiv rygning og blandt andet cancer og hjerte-karsygdomme. 
13 Af figur 3 fremgår det, at der kun vedtages én lov i Sverige i 1980'erne. Dette kan umiddelbart se ud til at stå i kontrast til tendensen til, at styringsambitionerne voksede i perioden. Kontrasten er dog kun umiddelbar, eftersom der i perioden udkom en del betænkninger, der i 1990'erne udmøntede sig i love.

14 Dette skifte er i overensstemmelse med WHOs definition af rygning.

15 Klassificeringen af tobaksrygning som en sygdom stemmer overens med internationale klassifikationer i perioden, blandt andre Davis, Novotny and Lynn 1988.

16 "STOP"-kampagnen hed, da den startede i 1995 "STOP 95".

17 Der har dog siden 1962 været indgået frivillige aftaler mellem Indenrigsministeriet og Cigar- og Tobaksfabrikanternes medlemmer om at afgrænse sig fra tobaksreklamer i medier direkte henvendt til børn og unge (Indenrigsministeriet, 1964:15).

18 Desuden publiceredes i samme periode en række internationale epidemiologiske forskningspublikationer om rygningens skadelige virkninger blandt andet på arbejdspladsen (Verwohlt, Reinbacher og Glümer, 2013).

19 I 2008 fremsattes imidlertid en ny proposition for forebyggelse, som lægger mere op til individuelt orienterede tiltag end tidligere (Vallgårda, 2008:3348-3349). Propositionen ændrer dog ikke ved, at den svenske forebyggelse er mere strukturorienteret end den danske.

20 Med offentlige rum menes i denne sammenhæng følgende arenaer: Folkeskoler, fritidsog ungdomsklubber, ungdomsuddannelser, arbejdspladser, sygehuse, værtshuse og caféer, restauranter, butikscentre, idrætsklubber og sportshaller, børnehaver, vuggestuer og offentlige kontorer. Undtagelser herfra er enkeltmandskontorer, dertil indrettede rygerum eller rygebokse samt serveringssteder på under $40 \mathrm{~m} 2$, hvor der kun serveres drikkevarer.

21 Afgiftsstigningerne i 2006 og 2009 sker i en periode, hvor der af den daværende regering var indført skattestop. Når Afgiftsstigninger alligevel var mulige, skyldes det, at afgifter på fødevarer i denne periode ikke betegnedes som en skat.

22 Siden 1999 har WHO prioriteret de forebyggende tiltag i forhold til hinanden, og de strukturelle orienteringer, og især prisreguleringer har højeste prioritet (WHO, 1999:72). Således italesætter alle inddragne WHO-publikationer også tobaksafgifter som forebyggelsestiltag.

23 Fra 1950 til 1972 er der to afgiftssatser for cigaretter, én for dyre og én for billige cigaretter. Kurven i figur 2 illustrerer gennemsnittet af disse to satser. Fra 1973 og frem ændres afgiftssatserne til i stedet at bestå af én afgiftssats samt en procentsats af detailprisen.

24 Kampagnen blev pilottestet i Danmark i 2004.

25 Der indførtes også strukturorienterede tiltag i løbet af 1980erne og 1990erne, eksempelvis lov om røgfrie miljøer i offentlige lokaler og transportmidler. Disse var dog af mindre intervenerende art end tiltagene i 2000erne.

26 Hen-Ry er et eksempel på en af de få foreninger i perioden, da hverken rygere eller ikke-rygere var særligt velorganiserede. Foreningen oprettedes som modbalance til Tobaksskaderådet, som etableredes samme år, og ophørte i år 2000, da det blev offentliggjort, at foreningen modtog penge fra tobaksfirmaet Philip Morris (Albæk, 2004:4).

27 På engelsk henvises til handlingerne som 'self-regarding' actions og 'other-regarding' actions (Garner, Ferdinand and Lawson, 2012:96-97).

28 Inertibegrebet defineres her i overensstemmelse med Hannan og Freeman som den mekanisme, at beslutningstagere responderer langsomt på forandringer i omgivel- 
serne og kun langsomt adresserer disse forandringer som indsatsområder (Hannan and Freeman, 1984:151).

29 Ottawa chartret anses ofte som startskuddet til, at sundhedsfremme kom højt på dagsordenen i international politik.

\section{Referencer:}

Albæk, E. (2002). "Holy smoke - no more? Tobacco control in Denmark" Arbejdspapirer fra Institut for Økonomi, Politik og Forvaltning, Aalborg Universitet.

Albæk, E. (2004). "Eksperter kan være gode nok, men- Om fagkundskabens politiske vilkår i dansk demokrati" Magtudredningen, Aarhus Universitetsforlag.

Avnstrøm, A. L. og Poulsen, S. (2006). "Dansk rygepolitik: Policyanalyse af den statslige rygepolitik - om passiv rygning" speciale, Roskilde Universitet.

Bardenfleth, N. G. og Madsen P. T. (2000). "Tobaksindustrien 1875-2000: Cigar og tobaksfabrikanternes forening af 20. juni 1875" Tobaksindustrien.

Borg, V. (2004). "Passiv rygning - et problem indenfor restaurationsbranchen: rapport til BAR service og tjenesteydelser" Arbejdsmiljøinstituttet, eksp. Arbejdsmiljørådets Servicecenter.

California Department of Public Health (1963). "State Department of Public Health; a summary of opinion; a proposal for action" Berkeley.

Clausen, E. (1961). “Unge - penge - tobak" Landsforeningen til Kræftens Bekæmpelse.

Clemmensen, I. et al (red.) (2005). "Hvidbog om passiv rygning" udgivet af 16 sundhedsfaglige organisationer.

Crombie, I. et al. (2005). "Closing the Health Inequalities Gap: An international perspective" World Health Organization.

David, A. et al C. (2010). »Tobacco use: equity and social determinants« In Blas, Erik and Kurup, Anand (edit.): „Equity, Social Determinants and Public Health Programmes« World Health Organization.

Davis, R., Novotny, T. and Lynn, W. (edit.) (1988). "The health consequences of smoking: Nicotine addiction: A report of the Surgeon General" Center for Promotion and Education, Office on Smoking and Health, USA.

Doll, R. and Hill, B. (1950). »Smoking and carcinoma of the lung; preliminary report« in: »British Medical Journal« 2:739.

Døllner, T. (1989). »Nej tak! lærerens bog om tobak og rygning - fase 1: Røgfri årgang « Tobaksskaderådet.dst.dk , Danmarks Statistik. d. 5. marts 2012.

Ekholm, O. et al (2006). »Sundhed og sygelighed 2005 og udviklingen siden 1987« Statens Institut for Folkesundhed.

Fællesudvalget (1961). »Betænkning fra Fællesudvalget vedrørende spørgsmålet om tobak-specielt cigaretter og lungekræft« Bianco Lunos Bagtrykkeri.

Folketinget (2007). Lov om røgfrie miljøer, Lov nr. 512 af 06/06/2007.

Forey, B. et al (2002). »International smoking statistics« Oxford University Press.

Garner, Robert, Ferdinand, Peter and Lawson, Stephanie (2012). »Introduction to politics, second edition « Oxford.

Glümer et al (2010). »Sundhedsprofil 2010 - Forebyggelse« Forskningscenter for Forebyggelse og Sundhed, Region Hovedstaden. 
Gostin, L. (1997). “The legal regulation of smoking (and smokers)” In: Brandt, Allan and Rozin, Paul (edit.): "Morality and Health" Routledge.

Griberg, S. (2007). »Fra lægemiddel til merkantil stimulans: tobakkens historie« i: »Alt om historie 1 10:56-59.

Hannan, M. and Freeman, J. (1984). "Structural inertia and organizational change« in: »American Sociological Review« 49(2):149-164.

Hirayama, T. (1981). »Non-smoking wives of heavy smokers have a higher risk of lung cancer - a study from Japan« In: »British Medical Journal« 282(6259):183-185.

Hogsted, C. et al. (2008). »Health for all? A critical analysis of public health policies in eight European countries « Swedish National Institute of Public Health.

Horn, D. (1962). "Smoking and Health: A report of the Royal College of Physicians of London on smoking in relation to cancer of the lung and other diseases" in: »Journal for Clinicians« Vol. 12(3):111-112.

Indenrigsministeriet (1964). »Betænkning om foranstaltninger til nedsættelse af cigaretforbruget: Afgivelse af det af Indenrigsministeriet under 29. maj 1963 nedsatte udvalg«, Indenrigsministeriet.

Jørgensen, Torben (2011). "Forebyggelse af kroniske sygdomme - den næste store medicinske triumf?" i: "Bibliotek for læger 3: Tidsskrift for medicinens historie, kultur, filosofi og metode" Lægeforeningen 203. årgang:236-249.

Kjøller, M., Juel, K. og Kamper-Jørgensen, F. (red.) (2007). »Folkesundhedsrapporten Danmark 2007 « Statens Institut for Folkesundhed.

Kræftens Bekæmpelse (2001). »STOP« Nyhedsbrev, nr. 25.

Larsen, L. T. (2008). "The political impact of science: is tobacco control science- or policydriven?" In: "Science and Public Policy" 35(10):757-769.

Levin, M., Goldstein, H. and Gerhardt, P. (1950). „Cancer and tobacco smoking: A preliminary report« In: »Journal of the American Medical Associaltion« Vol 143(4):336-338.

Lov nr. 512 af 06/06/2007, Lov om røgfri miljøer, Ministeriet for Sundhed og Forebyggelse.

Mik-Meyer, N. og Villadsen, K. (2007). »Magtens former: Sociologiske perspektiver på statens møde med borgeren « Hans Reitzel.

Mill, J. S. (1859). »On Liberty« Longman, Roberts, \& Green Co.

Neergaard, H. (2007). »Udvælgelse af cases i kvalitative undersøgelser« Forlaget Samfundslitteratur.

Nielsen, P. (2000). „Fra hellig rog til det rene gift: et historiemateriale om holdninger til tobak gennem tiden« Kræftens Bekæmpelse.

Nielsen, T. og Nygaard, J. (1982). »Tobak - op i røg?« Haase.

OECD Health Data (2011).«Tobacco consumption \% of adult population who are daily smokers« Tilgængelig på: http://www.oecd.org/document/16/0,3343, en_2649_34631_2085200_1_1_1_1,00.html.2011.

Regeringen (1989). »Regeringens forebyggelsesprogram. Dokumentationsdel og programdel« Regeringen.

Regeringen (2002a). »Mål för folkhälsan: Regeringens proposition 2002/03:35« Sosialdepartementet.

Regeringen (2002b). Sund hele livet: De nationale mål og strategier for folkesundheden.

Rimpelä, M. (1977). »Från forskning till intervention - mot en hälsoinriktad tobakspolitik« i: »Nordisk Medicin« 93:73-78. 
Sjølin, K.E. et al (1969). »Tobaksproblemet: En orientering om oplysningsarbejdets metodik og faglige grundlag « Indenrigsministeriet.

Snowdon, C. (2009). »Velvet glove, iron fist: A history of anti-smoking «ittle Dice.

Socialstyrelsens Tobaksutredning (1973). »Tobaksrökning: en rapport från Socialstyrelsens tobaksutredning « Sosialstyrelsen.

Stobbe, E. (1993). »Lad os leve - og ryge« i: »Smag og behag« 3.

Sundhedsministeriets Middellevetidsudvalg (1994). »Levetiden i Danmark« (delrapport) Statens Information, eksp. Gyldendal.

Sundhedsstyrelsen (2004). »Sig nej til tobaksforurenet luft« Sundhedsstyrelsen.

Sundhedsstyrelsen (2009). »Hver eneste cigaret skader dig: Få hjælp til at blive røgfri« Sundhedsstyrelsen.

Sundhedsstyrelsen, sst.dk. d. 13. januar 2012.

Surgeon General (1964). »The 1964 Report on Smoking and Health« National Institutes of Health, Department of Health \& Human Services, USA.

Svenska Läkartidningen (1982) (79). Sveriges läkarförbund.

Tobaksskaderådet (1989). »WHOs 5 års handlingsplan for et røgfrit Europa« Tobaksskaderådet.

Torell, U. (2002). »Den rökande människan: bilden av tobaksbruk i Sverige mellan 1950- och 1990tal« Carlsson Bokförlag.

Vallgårda, S. (2003). »Folkesundhed som politik: Danmark og Sverige 1930 til i dag« Aarhus Universitetsforlag.

Vallgårda, S. (2008). »Kursskifte i svensk tobakspolitik: You can do it your own way; if it's done just how I say« i: »Ugeskrift for læger« 170(42):3348-3349.

Vallgårda, S. og Koch, L. (2007). »Forskningsmetoder i folkesundhedsvidenskab« Munksgaard Danmark.

Verwohlt, B. og Reinbacher, G. (2012). »Etik i folkesundhed: Mellem individuelt og samfundsmæssigt fokus« i Kjærsdam, Patrik og Pahuus, Mogens (red.): »Aktuelle etiske udfordringer: Bidrag til anvendt etik« Aalborg Universitetsforlag.

Verwohlt, B., Reinbacher, G. og Glümer, C. (2013). "'It's my own choice! But I choose to be compliant' Changing attitudes towards the Danish Smoking law in public places, 2007-2010« In press.

WHO (1964). »Prevention of Cancer« in: »World Health Organization Technical Report Series« No. 276, World Health Organization.

WHO (1986). »The Ottawa Charter for Health Promotion. First international conference on health promotion 21st November 1986« World Health Organization.

WHO (1999). »The World Health Report 1999: Making a difference« World Health Organization «.

Wier, M. at al (2009). »Vi kan leve længere og sundere: Forebyggelseskommissionens anbefalinger til en styrket forebyggende indsats « Forebyggelseskommissionen.

Wingård (1951). “Underliga ämnen: några blad ur vetenskapens historia" i: "Natur och Kultur".

Wynder, E. and Graham, E. (1950). »Tobacco smoking as a possible etiologic carcinoma: A study of six hundred and eighty-four proved cases « In: »Journal of the American Medical Association« 143(4):329-336. 